\title{
Yaygın Eğitim Kurumlarında Görev Yapan Usta Öğretici ve Kadrolu Öğretmenlerin Öğretmen Liderliğine İlişkin Bakış Açıları
}

\section{Dr.Reyhan Şekerci ${ }^{1^{*}}$ Doç.Dr.Süleyman Karataş ${ }^{2}$}

Gelis tarihi: 08.05.2019

Kabul tarihi: 24.05.2019

\section{Atıf bilgisi:}

Uluslararası Bilimsel Araștırmalar Dergisi (IBAD)

Cilt: $4 \quad$ Sayı: 2

Sayfa: 425-434 Yll: 2019

Dönem: Yaz

This article was checked by Turnitin. Similarity Index 09\%

\footnotetext{
${ }^{1}$ Konyaaltı Halk Eğitimi Merkezi, Türkiye, rnazaroglu@hotmail.com ORCID ID 0000-0002-9348-2621

2Akdeniz Üniversitesi,

Türkiye, skaratas07@gmail.com, ORCID ID 0000-0003-0002-2886
}

\section{* Sorumlu Yazar}

\begin{abstract}
öz
$\mathrm{Bu}$ çalışmanın amacı, yaygın eğitim kurumlarında görev yapan kadrolu öğretmen ve usta öğreticilerin öğretmen liderliğine ilișkin bakıs açılarının ortaya konulmasıdır. Nitel araştırma yönteminin kullanıldığı bu araştırmaya amaçlı örnekleme yöntemlerinden kolay ulaşılabilir durum örneklemesi ile belirlenen 6 kadrolu öğretmen ve 6 usta öğretici katılmıştır. Araştırma nitel araştırma desenlerinden olgu bilim desenindedir. Bu nedenle araştırmada da veri toplamak amacı ile yarı yapılandırılmış görüşme formu hazırlanarak görüşme tekniği kullanılmıștır. Veriler içerik analizi tekniği ile çözümlenmiştir. Araştırmada elde edilen tüm veriler kodlanmış, araştırmanın amacına uygun olarak çeşitli boyutlar ve bu boyutlara uygun temalar saptanmış, temalara ilişkin yüzde ve frekanslar hesaplanmıştır. Verilerin analizinde ayrıca içerik analizi yapılarak, katılımcıların görüşlerine ayrıntılı olarak yer verilmiştir. Araştırma sonucunda genel olarak tüm katılımcıların öğretmen liderliği kavramına dair farkındalıkları olduğu, daha önce az da bir bilgilerinin olduğu ancak bu kavramı daha çok sınıf yönetimi ve bazı idari görevlerin paylaşılması şeklinde değerlendirdikleri saptanmıştır.
\end{abstract}

Anahtar Kelimeler: Kadrolu öğretmen, usta öğretici, öğretmen liderliği 


\title{
The Viewpoints of Master Trainers and Staffed Teachers Working in Informal Education Institutions on Teacher Leadership
}

\author{
Dr. Reyhan Şekerci ${ }^{1 *}$ \\ Assoc. Prof. Dr. Süleyman Karataş ${ }^{2}$
}

First received: 08.05.2019

Accepted: 24.05 .2019

\section{Citation:}

Journal of the International

Scientific Research (IBAD)

Volume: 4 Issue: 2

Pages: 425-434 Year: 2019

Session: Summer

This article was checked by Turnitin. Similarity Index 09\%

\footnotetext{
${ }^{1}$ Konyaaltı Halk Eğitimi Merkezi, Türkiye, rnazaroglu@hotmail.com ORCID ID 0000-0002-9348-2621

2 Akdeniz Üniversitesi,

Türkiye, skaratas07@gmail.com,
} ORCID ID 0000-0003-0002-2886

* Corresponding Author

\begin{abstract}
The purpose of this study is to reveal the viewpoints of master trainers and staffed teachers working in informal education institutions on teacher leadership. Six staffed teachers and six master trainers who were determined with convenience sampling, which is among purposeful sampling methods, participated in the study that was conducted using qualitative research method. The study was conducted in phenomenological design, which is among qualitative research designs. Thus, in order to collect data in the study, a semi-structured interview form was prepared and the interview technique was used. The data were analyzed using the content analysis technique. All the data acquired in the study were coded, various dimensions and convenient themes were determined in accordance with the study purpose and finally, percentages and frequencies concerning the themes were calculated. A theme analysis was also performed in the analysis of the data and the participants' viewpoints were included extensively. As a result of the study, it was determined that all the participants were aware of the concept of teacher leadership that they received in general and already had some information before but evaluated this concept mainly as sharing the classroom management and some administrative tasks.
\end{abstract}

Keywords: Staffed teacher, master trainer, teacher leadership. 


\section{INTRODUCTION}

Education is not limited only with schools and predetermined curriculum; instead, it extends to the whole life and every area of life. In addition, it appears in different forms to meet the changing needs and keep pace with the necessities of the time. The educational needs that cannot be met by current curricula in formal education system can be realized with informal education activities where individuals from all ages can participate (Karakütük, 1990). When assessing informal education in general, it is indicated that formal education and informal education complete one another and learning continues for a lifetime in line with the principle of sustainability, which is one of the fundamental principles of the Turkish National Education System.

Used synonymously with concepts like informal and continuing education, lifelong learning is defined by Candy (2003) as a supportive process which enhances and strengthens the knowledge, values, skills, and understandings acquired by individuals throughout their lives and enables them to apply these things in real life. Aksoy (2008, s. 35) defines lifelong learning as the documentation of formal, informal and life lesson activities in which individuals participate throughout their lives and the outcomes of these activities for the purpose of improving their competences regarding knowledge, skills, attitudes and behaviors by determining their fields of interest with an individual, social, cultural, economic and especially employment-related approach. Friessen and Anderson (2004) indicate that lifelong learning comprises all kinds of learnings from formal education to informal education which are classified according to ages; from programmed, planned and intended learnings to random and need-related learnings that occur in working life or from learnings required by society to optional learnings.

The ever-changing world and society affect individuals who are the inputs of the system of education and indirectly schools. Educational institutions, educational administrators, teachers and students have to keep pace with the change. Education is not only a means of changes, but also a process of adapting individuals to changing conditions and strengthening them to cope with some problems caused by the change. In the literature, it is indicated that formal structures determined for the organization to fulfil its functions within this continuous change are not sufficient alone. Effective and modern schools should aim to raise assertive individuals who can have the freedom of thinking multi-directionally, internalize their own culture, and have a vision (Can, 2009a). Teachers play an undeniable role in the process of raising students. Leadership roles of teachers are more effective on managing and changing students' behaviors. In this respect, teacher leadership aims to allow students to participate in educational activities in the classroom and also raise individuals who are always ready for continuous learning (Can, 2009a). There are numerous studies on teacher leadership in the literature (Katzenmayer and Moller, 2009; Scot, 2011; Kılınç ve Recepoğlu, 2013). For examples, Beycioğlu and Aslan (2012) express the need for teacher leadership as follows: Schools which are among the leading institutions of society are also affected by the changes of the time. Schools are today expected to become functional not only from the educational aspect, but also from the organizational aspect that is open to society and students' emotional side, accepts social diversity, has a higher sensitivity toward technology, improves and protects their spiritual value in the eyes of society, collaborates with wage earners, teaches democracy and acts democratically while teaching it, is ready for the competitive environment of today's world, resists harmful effects of the external environment without getting detached from the tangible side of life, questions their own structure while doing all these, and is open to change. In order to realize this, it is a primary prerequisite to display innovative and effective leadership behaviors in school administration.

From this point of view, the teacher as an educational leader in school should be able to dominate and influence the classroom and create a classroom vision. Teachers in schools should not only display formal leadership behaviors such as educational leadership and department presidency, but also play leadership roles in informal groups (Can, 2009b). Leadership behaviors displayed by teachers who lead formal and informal groups in schools are among the principal factors creating the school culture. It is important for a teacher who displays leadership features in the classroom to create a free classroom atmosphere, prepare a proper classroom climate where students can express themselves, and prevent factors that may deteriorate this climate (Can, 2009b). It is possible to think that this condition is important and effective for school shareholders to feel that they belong to the school, adopt school, 
display gallant behaviors, prioritize conscience in their acts and display benevolence behaviors. Thus, the aim of this study is to determine the viewpoints and awareness of master trainers and staffed teachers working in informal education institutions on teacher leadership. In order to achieve this goal, the following questions were tried to be answered:

1. What are the viewpoints of staffed teachers working in informal education institutions on teacher leadership?

2. What are the viewpoints of master trainers working in informal education institutions on teacher leadership?

\section{METHOD}

\section{Research Design}

According to Karasar (2009), this study was conducted using descriptive screening model which tries to describe a case and subject individually. In order to perform that description profoundly, qualitative research technique was used in the study and the study was conducted in the phenomenological design, which is among qualitative research designs (Turgut, 2009). Thus, the interview technique was also used in the study to collect the data and a semi-structured interview form was prepared for this purpose.

\section{Sample Group}

Sample group was selected from the master trainers and staffed teachers working in a school which provides informal education in Konyaaltı district of Antalya province in the study. In addition, convenient sampling, being one of purposeful sampling methods, was used in the study. Thus, the sample consisted of a total of twelve participants including six staffed teachers and six master trainers working in an informal education institution. According to the order of interviews; the staffed teachers were coded as S1, S2, S3, S4, S5, S6 and the master trainers were coded as M1, M2, M3, M4, M5, and M6 (Kuş, 2007; Mason J. 2002; Patton, 1990; Rubin and Rubin, 1995; Yıldırım and Şimşek, 2006).

Personal Characteristics of the Sample Group

Table 1. Demographic Characteristics of the Master Trainers

\begin{tabular}{|c|c|c|c|c|c|c|c|c|}
\hline Variable & Code & M1 & M2 & M3 & M4 & M5 & M6 & $\mathrm{f}$ \\
\hline \multirow{2}{*}{ Duty } & Retired MT & $\sqrt{ }$ & & $\sqrt{ }$ & $\sqrt{ }$ & & & 3 \\
\hline & Normal MT & & $\sqrt{ }$ & & & $\sqrt{ }$ & $\sqrt{ }$ & 3 \\
\hline \multirow{2}{*}{ Gender } & $\mathrm{F}$ & & $\sqrt{ }$ & & & $\sqrt{ }$ & $\sqrt{ }$ & 3 \\
\hline & M & $\sqrt{ }$ & & $\sqrt{ }$ & $\sqrt{ }$ & & & 3 \\
\hline Educational & Associate's Degree & $\sqrt{ }$ & $\sqrt{ }$ & $\sqrt{ }$ & & & & 2 \\
\hline \multirow[t]{3}{*}{ Background } & Bachelor's Degree & & & & $\sqrt{ }$ & $\sqrt{ }$ & & 2 \\
\hline & Postgraduate & & & & & & $\sqrt{ }$ & 1 \\
\hline & General & $\sqrt{ }$ & & & & & & 1 \\
\hline \multirow[t]{2}{*}{ Course Type } & $\begin{array}{l}\text { Occupational/ } \\
\text { Art }\end{array}$ & & $\sqrt{ }$ & $\sqrt{ }$ & $\sqrt{ }$ & $\sqrt{ }$ & $\sqrt{ }$ & 5 \\
\hline & $0-10$ years & $\sqrt{ }$ & & & & & & 1 \\
\hline Seniority & 10 years and over & & $\sqrt{ }$ & $\sqrt{ }$ & $\sqrt{ }$ & $\sqrt{ }$ & $\sqrt{ }$ & 5 \\
\hline
\end{tabular}

When examining the demographic characteristics of the master trainers; it is seen that half of those who were interviewed were retired and the half were in a normal status. Their gender status also showed a balanced distribution. While half of them had an associate's degree, only one had a postgraduate degree. Master trainers were mainly in occupational and art branches and almost all of them had a seniority of 10 years and over. The working duration of almost all of them has been limited with one year in their informal education institutions and their possibility of reassignment was limited with the score to be obtained according to their application in the beginning of education and convenience for assignment 
criteria, as well as the commission decision based on the recent regulation in informal education institutions.

Table 2. Demographic Characteristics of the Staffed Teachers

\begin{tabular}{|c|c|c|c|c|c|c|c|c|}
\hline Variable & Code & $\mathrm{S} 1$ & $\mathrm{~S} 2$ & S3 & $\mathrm{S} 4$ & S5 & S6 & f \\
\hline \multirow{2}{*}{ Duty } & Administrator & $\sqrt{ }$ & & & & $\sqrt{ }$ & $\sqrt{ }$ & 3 \\
\hline & Teacher & & $\sqrt{ }$ & $\sqrt{ }$ & $\sqrt{ }$ & & & 3 \\
\hline \multirow{2}{*}{ Gender } & $\mathrm{F}$ & & $\sqrt{ }$ & & & $\sqrt{ }$ & $\sqrt{ }$ & 3 \\
\hline & M & $\sqrt{ }$ & & $\sqrt{ }$ & $\sqrt{ }$ & & & 3 \\
\hline Educational & Bachelor & $\sqrt{ }$ & & & & & $\sqrt{ }$ & 2 \\
\hline \multirow[t]{3}{*}{ Background } & Postgraduate & & $\sqrt{ }$ & $\sqrt{ }$ & $\sqrt{ }$ & & & 3 \\
\hline & Doctorate & & & & & $\sqrt{ }$ & & 1 \\
\hline & General & $\sqrt{ }$ & & $\sqrt{ }$ & & $\sqrt{ }$ & & 3 \\
\hline Branch & Occupational/Art & & $\sqrt{ }$ & & $\sqrt{ }$ & & $\sqrt{ }$ & 3 \\
\hline Seniority & $\begin{array}{l}0-10 \text { years } \\
10 \text { years and over }\end{array}$ & $\sqrt{ }$ & $\sqrt{ }$ & $\sqrt{ }$ & $\sqrt{ }$ & $\sqrt{ }$ & $\sqrt{ }$ & 6 \\
\hline
\end{tabular}

When examining the demographic characteristics of the staffed teachers, it was seen that the variables of duty type and gender were distributed in a balanced way. Administrators were also included in the sample group because they wanted to participate in the training program voluntarily and as a teacher. Educational background of the participants was generally bachelor's degree and higher education. It was seen that there was a balanced distribution on the basis of branch. All of the participants had a seniority of 10 years and over. Although not included in the table, the participants all consist of staffed teachers who worked in the same institution for at least 1 year and over.

\section{Data Collection Tools}

The interview questions were prepared using a literature review and examined by a field expert. Preliminary application of the interview questions was performed by a teacher, an administrator and a student outside the participants. The interview questions were finalized based on the feedback received from these interviews. The interview questions consist of ten questions. The semi-structured interview form includes questions about positive aspects and contributions of teacher leadership.

The participants to be interviewed were informed about the purpose of the study and the teachers, administrators and students who wanted to participate in the study were determined on a voluntary basis. Notes were taken by the researcher synchronically with the interviews. The interviews lasted for about 30-50 minutes. The interviews were conducted between September and November 2018 at the course centers and in an available classroom at the same places with course attendees.

\section{Data Analysis}

In the study, the qualitative data acquired from the interviews were analyzed using content analysis, which includes the stages of coding, finding the themes and organizing the data according to the codes and themes (Balc1, 2004; Yıldırım and Şimşek, 2011). The interviews recorded were put in writing by the researchers in the computer environment. Then, all the data acquired in the study were read many times and coded. During the process of coding, various dimensions were determined in line with the study purpose and the themes were determined according to these dimensions. In order to provide the reliability of the analyses, another researcher recoded the interview texts. A considerable consensus was achieved among the codings of the researcher and another expert in order for validity and reliability to provide the objectivity of a good qualitative research (Morse et al., 2002) and it was concluded that the coding had been performed in a reliable way. 


\section{FINDINGS}

This section includes results acquired in relation with the participants' viewpoints concerning the general viewpoints of the master trainers and staffed teachers on teacher leadership, as well as interpretations of these results.

\section{General Viewpoints of the Master Trainers on Teacher Leadership}

Table 3. General Viewpoints of the Master Trainers on Teacher Leadership

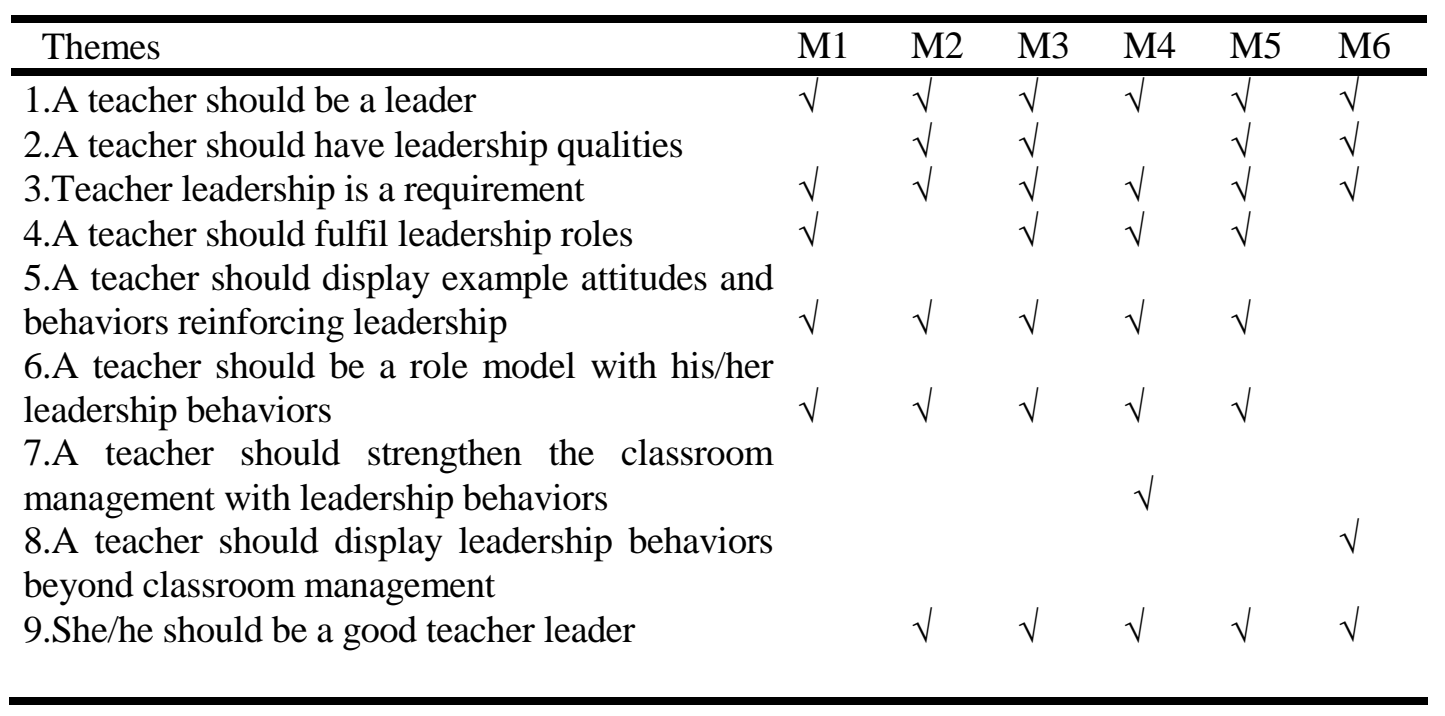

Table 3. General viewpoints of the master trainers on teacher leadership are as follows:

"I think that the teachers should display teacher leadership behaviors and roles in the classroom as an example for our students to set their goals, work willingly and have self-confidence. They should be determined, patient, instructive and disciplined as much as possible." M1 $(1,3,4,5,6)$

"A teacher's leadership signifies being productive, expert and appropriate for leadership qualities. As a matter of fact, the teacher should be leader in education. " M2(1,2,3,5,6,9)

"A teacher should always display example behaviors toward the people for him she/he is responsible. This necessity is of great importance." M3(1,2,3,4,5,6)

"A teacher should be an example person and also be good at crisis management. She/he should be self-confident and have comprehensive knowledge. All these are very necessary for leadership and classroom management in the classroom, as well." M4(1,3,4,5,6,7,9)

"Individuals with leadership qualities should be fair, solution-oriented, objective, charismatic, respectful, social, problem-solving, self-expressive and should also have a proper diction. It is of great importance for a teacher to have leadership qualities. " M5 (1,2,3,4,5,6,9)

"A leader teacher should have good educational knowledge, high self-confidence and selfexpression and be clear. In addition, she/he should produce new things and display other leadership skills outside classroom management." M6(1,2,3,8,9) 


\section{Viewpoints of the Staffed Teachers on Teacher Leadership}

Table 4. General Viewpoints of the Staffed Teachers on Teacher Leadership

\begin{tabular}{|c|c|c|c|c|c|c|}
\hline Themes & S1 & $\mathrm{S} 2$ & S3 & S4 & S5 & S6 \\
\hline 1.A teacher should be a leader & $\sqrt{ }$ & $\sqrt{ }$ & $\sqrt{ }$ & $\sqrt{ }$ & $\sqrt{ }$ & $\sqrt{ }$ \\
\hline 2.A teacher should have leadership qualities & & & $\sqrt{ }$ & & & $\sqrt{ }$ \\
\hline 3.Teacher leadership is a requirement & $\sqrt{ }$ & $\sqrt{ }$ & $\sqrt{ }$ & $\sqrt{ }$ & $\sqrt{ }$ & $\sqrt{ }$ \\
\hline $\begin{array}{l}\text { 4.A teacher should fulfil leadership roles } \\
\text { 5.A teacher should display example attitudes and } \\
\text { behaviors reinforcing leadership }\end{array}$ & $\sqrt{ }$ & $\sqrt{ }$ & $\sqrt{ }$ & $\sqrt{ }$ & $\sqrt{ }$ & $\sqrt{ }$ \\
\hline $\begin{array}{l}\text { 6.A teacher should be a role model with } \\
\text { leadership behaviors }\end{array}$ & $\sqrt{ }$ & $\sqrt{ }$ & $\sqrt{ }$ & $\sqrt{ }$ & $\sqrt{ }$ & $\sqrt{ }$ \\
\hline $\begin{array}{l}\text { 7.A teacher should strengthen the classroom } \\
\text { management with leadership behaviors } \\
\text { 8.A teacher should display leadership behaviors } \\
\text { beyond classroom management }\end{array}$ & $\sqrt{ }$ & $\sqrt{ }$ & $\sqrt{ }$ & $\sqrt{ }$ & $\sqrt{ }$ & $\sqrt{ }$ \\
\hline 9.She/he should be a good teacher leader & & & $\sqrt{ }$ & & & $\sqrt{ }$ \\
\hline
\end{tabular}

Table 4. General viewpoints of the staffed teachers on teacher leadership were as follows:

"A teacher should care about their students from all aspects and help them build their lives. Among these things, determining the students' competences and shaping their future according to these competences are of prime importance. A teacher should prioritize this and consequently take the necessary step. Then she/he will complete building the students' structure with auxiliary materials like education and training. The teacher's leadership roles and behaviors are of great importance because during adolescence, children spend time with their teachers the most and take them as role a model. " SI $(1,3,4,5,6,7)$

"Teacher leadership is a leadership displayed by the teacher to guide her/his students in all activities performed in the classroom. I think we confuse it with classroom management a little. Motivating a student group in line with goals, reaching all the students individually and providing an active participation in the educational process in the classroom. Although I know what leadership is, I am not so sure with what behaviors can display it in the classroom. I don't know how to put it into practice. Because teacher leadership is more like an independent and creative leadership rather than an administrative leadership." $S 2(1,3,5,6,7,8)$

"A teacher is already a leader in the classroom. She/he should extend it to the school or to a broader framework. The teacher is a guide and a mentor. She/he sets an example in doing a lot of things. Thus, she/he is really necessary. She/he fulfils this role for either her/his students, colleagues or other social circle. She/he also needs to be a good leader in directing the parents and organizing activities. "S3(1,2,3,4,6,7,9)

"Being determined-consistent is very essential. Motivating is a must. Inspiring is a must, as well." $S 4(1,3,4,5,6,7)$

"Actually, she/he is everything. A teacher is a role model in the first place. She/he is an example person. Therefore, all her/his behaviors are related with leadership. That's the way it should be. Teachers have great roles and tasks on this subject in the social aspect." S5(1,3,4,5,6,7,8)

"A teacher should be a creative leader. Because being a role model requires this." $S 6(1,2,3,4,6,8,9)$ 


\section{DISCUSSION, CONCLUSION AND IMPLICATIONS}

When considering the study results in general; the participants stated that they had heard of the concept of teacher leadership before, thought that it could be related with leadership, but did not know exactly how to apply it in education and reflect it to the course areas and their classrooms. This coincides with the finding of Beycioğlu (2009) that teachers are aware of the necessity and display level of teacher leadership behaviors in schools.

Among master trainers and teachers working in informal education institutions, especially master trainers stated that they had a difficulty in solving the problems and distresses they faced in the courses because they were working in the areas far from the course center (such as villages, far neighborhoods, towns) and also faced many other problems due to the waste of time experienced while reaching the administrators and managers in charge and conveying their problems immediately. Thus, they reported that the concept of teacher leadership was really important for them and it had to be transferred to educational environments. There are numerous studies on teacher leadership in the literature (Katzenmayer and Moller, 2009; Scot, 2011; Kılınç and Recepoğlu, 2013).

The staffed teachers, on the other hand, stated that they had obtained a little knowledge about the subject before, but that kind of leadership applications were mostly limited with administrative and managerial tasks in institutions, and were mainly perceived as sharing an administrator's tasks. Similarly, Can (2010) and Beycioğlu (2009) stated that teacher leadership behaviors were known as a concept by teachers in present schools. However, Can (2010) stressed that the aforementioned behaviors were mostly confused with classroom management and administrative skills by school principals.

In addition, all of the administrators who participated in the study think that it would be wrong to expect all of the leadership and administrative skills only from the administrators in charge. They suggested that it was necessary to include all the participants working in the institution in administrative processes. A particular emphasis was laid on the necessity for teachers to acquire leadership skills and strengthening teacher leadership in areas that are inclined to flexible, independent and creative educational activities, such as informal education institutions. Beycioğlu (2010) therefore suggests that development of teacher leadership is among prerequisites in order to display innovative and effective leadership behaviors in administration of schools.

Thus, it can be asserted that renewing the assignment and job definitions of administrators in charge at different times and transforming and changing the responsible areas instead of keeping the administrators responsible only for certain areas and regions will help them develop their leadership skills and strengthen teacher leadership by preventing certain teachers from being assigned constantly.

Bilgilendirme / Acknowledgement: Bu çalışma 10th International Congress on New Trends in Education/ 10'uncu Uluslararası Eğitimde Yeni Yönelimler Kongresi, 26-27 Nisan, Antalya’da sözlü bildiri olarak sunulmuştur.

\section{REFERENCES}

Aksoy, M. (2008). Yaşam boyu ögrenme ve kariyer rehberliği ilkelerinin istihdam edilebilirliğe etkileri: Otel işletmeleri üzerine bir uygulama. Yayınlanmamış doktora tezi, Gazi Üniversitesi Eğitim Bilimleri Enstitüsü, Ankara.

Balc1, A. (2004). Sosyal bilimlerde araştırma. Ankara: Pegem Yayıncılık.

Beycioğlu, K. (2009). İlköğretim okullarında ögretmenlerin sergiledikleri liderlik rollerine ilişkin bir değerlendirme. Yayımlanmamış doktora tezi, İnönü Üniversitesi Sosyal Bilimler Enstitüsü, Malatya. 
Beycioglu, K. ve Aslan, B. (2010). Öğretmen liderliği ölçeği: Geçerlik ve güvenirlik çalışması. Illkögretim Online, 9(2), 764-775.

Beycioğlu, K. ve Aslan, B. (2012). Öğretmen ve yöneticilerin öğretmen liderliğine ilişkin görüşleri: Bir karma yöntem çalışması. Kuram ve Uygulamada Eğitim Yönetimi, 2(2), 191-223.

Can, N. (2009a). Öğretmen liderliği. Ankara: Pegem Akademi Yayıncılık.

Can, N. (2009b). Öğretmenlerin sınıfta ve okulda liderlik davranışları, Gaziantep Üniversitesi Sosyal Bilimler Dergisi, 8(2), 385-399.

Can, N. (2010). Öğretmen liderliğinde müdürlerin etkisi. Dumlupınar Üniversitesi Sosyal Bilimler Enstitüsü Dergisi, 27, 57-66.

Candy, P. C. (2003). Lifelong learning and information literacy. Report for U.S. NationalCommission on Libraries and Information Science and National Forum on Information Literacy. Retrived on 22 January 2014, at URL: http://www.nclis.gov/libinter/infolitconf\&meet/papers/candyfullpaper.pdf

Çeken, R. (2011). "Bu Benim Eserim” Öğrenci Projelerinin Okul Türü Bakımından Değerlendirilmesi, Mehmet Akif Ersoy Üniversitesi Eğitim Fakültesi Dergisi, 11(22), 1-14.

Demir, E. (2008). Sinıf öğretmenlerinin ilköğretim programlarındaki değerlendirme sürecine ilişkin görüşleri (Eskişehir ili örneği).Yayımlanmamış yüksek lisans tezi, Eskişehir Osmangazi Üniversitesi Sosyal Bilimler Enstitüsü, Eskişehir.

Ertürk, S. (1994). Eğitimde program geliştirme. Ankara: Yelkentepe Yayınları.

Friessen, N. \& Anderson, T. (2004) Interaction for life-long learning. British Journal of Educational Technology, 35(6), 679-687.

Gelbal, S. ve Kellecioğlu, H. (2007). Öğretmenlerin ölçme değerlendirme yöntemleri hakkındaki yeterlik algıları ve karşılaştıkları sorunlar [Çevrimiçi sürüm]. Hacettepe Üniversitesi Eğitim Fakültesi Dergisi, 33, 135-145.

Güven, S. (2008). Sınıf öğretmenlerinin yeni ilköğretim ders programlarının uygulanmasına ilişkin görüşleri [Çevrimiçi sürüm]. Milli Ĕgitim Dergisi, 177, 224-236.

Hersan, E. (2008). 2004 yılı ilköğretim 5. sinıf sosyal bilgiler öğretim programına ilişkin veli görüşleri. Yayımlanmamış yüksek lisans tezi, Marmara Üniversitesi Eğitim Bilimleri Enstitüsü, İstanbul.

Karakütük, K. (1990). Yaygın eğitim harcamalarının değerlendirilmesi. Ankara Üniversitesi Eğitim Bilimleri Fakültesi Dergisi, 23(1), 195-211.

Karasar, N. (2009). Bilimsel araştırma yöntemi. Ankara: Nobel Yayın Dağıtım.

Katzenmeyer, M. \& Moller, G. (2009). Awakening the sleeping giant. helping teachers develop as leaders, 3. Bask1, ThousandOaks, CA: Corwin.

Kılınç, A. Ç., \& Recepoğlu, E. (2013). Ortaöğretim okulu öğretmenlerinin öğretmen liderliğine ilişkin alg1 ve beklentileri, Kalem Ë̆itim ve Insan Bilimleri Dergisi, 3(2), 175-215.

Kuş, E. (2003). Nicel-nitel araştırma teknikleri. Ankara: Anı Yayıncılık.

Kuş, E. (2007). Nicel-Nitel Araştırma Teknikleri. 2. Baskı. Ankara: Anı Yayıncılık.

Mason J. (2002). Qualitative researching. 2nd. Ed. London: Sage.

Morse, J. M., Barrett, M., Mayan, M., Olson, K. ve Spiers, J. (2002). Verification strategies for establishing reliability and validity in qualitative research, International Journal of Qualitative Methods, 1(2), 13-22.

Patton, M. Q. (1990). Qualitative evaluation and research methods. London: Sage.

Patton, M., Q. (1990). Qualitative evaluation and research. 2nd.Ed. California, USA: Sage. 
Rubin, H. ve Rubin, I. (1995). Qualitative interviewing: The art of hearing data. Thousand Oaks, CA: Sage.

Scott, P. D. (2011). Teacher Leadership Development at the Second Career Stage: Influential Factors, Challenges, and Systems Implications. Unpublished doctoral dissertation, University of Washington, USA.

Torun, O. (2003). Yeni Bir Mesleki Oluşum: Okul Kütüphanecileri İstanbul Grubu. Türk Kütüphaneciliği 17(1), 55-68.

Turgut, Y. (2009). Verilerin kaydedilmesi, analizi, yorumlanması: nicel ve nitel. Tanrı̈ğğen, A., (Ed.), Bilimsel araştırma yöntemleri. (s. 193-247). Ankara: Anı Yayıncılık.

Yıldırım, A. ve Şimşek, H. (2006). Sosyal bilimlerde araştırma yöntemleri. 6. Baskı. Ankara: Seçkin Yayınc1lı.

Yıldırım, A. ve Şimşek, H. (2011). Sosyal bilimlerde nitel araştırma yöntemleri (8. tıpkı basım). Ankara: Seçkin Yayıncılık. 